\title{
25-Hydroxylation of vitamin $D_{3}$ by a cytochrome $P-450$ from rabbit liver mitochondria
}

\author{
Helena DAHLBÄCK and Kjell WIKVALL \\ Department of Pharmaceutical Biochemistry, University of Uppsala, Box 578, S-751 23 Uppsala, Sweden
}

\begin{abstract}
A cytochrome $P-450$ catalysing 25 -hydroxylation of vitamin $D_{3}$ was purified from liver mitochondria of untreated rabbits. The enzyme fraction contained $9 \mathrm{nmol}$ of cytochrome $P-450 / \mathrm{mg}$ of protein and showed only one protein band with an apparent $M_{\mathrm{r}}$ of 52000 upon SDS/polyacrylamide-gel electrophoresis. The preparation showed a single protein spot with an apparent isoelectric point of 7.8 and an $M_{\mathrm{r}}$ of approx. 52000 upon two-dimensional isoelectric-focusing-polyacrylamide-gel electrophoresis. The purified cytochrome $P-450$ catalysed 25 -hydroxylation of vitamin $D_{3}$ up to 5000 times more efficiently than did the mitochondria. The cytochrome $P-450$ required both ferredoxin and ferredoxin reductase for catalytic activity. Microsomal NADPH-cytochrome $P-450$ reductase could not replace ferredoxin and ferredoxin reductase. The cytochrome $P-450$ catalysed, in addition to 25 -hydroxylation of vitamin $D_{3}$, the 25-hydroxylation of $1 \alpha$-hydroxyvitamin $\mathrm{D}_{3}$ and the 26-hydroxylation of $5 \beta$-cholestane-3 $\alpha, 7 \alpha, 12 \alpha$-triol. The enzyme did not catalyse side-chain cleavage of cholesterol, $11 \beta$-hydroxylation of deoxycorticosterone, $1 \alpha$-hydroxylation of 25 -hydroxyvitamin $\mathrm{D}_{3}$, hydroxylations of lauric acid and testosterone or demethylation of benzphetamine. The results raise the possibility that the 25 -hydroxylation of vitamin $D_{3}$ and the 26-hydroxylation of $\mathrm{C}_{27}$ steroids are catalysed by the same species of cytochrome $P-450$ in liver mitochondria. The possible role of the liver mitochondrial cytochrome $P-450$ in the metabolism of vitamin $D_{3}$ is discussed.
\end{abstract}

\section{INTRODUCTION}

The first step in the bioactivation of vitamin $\mathrm{D}_{3}$ is a 25 -hydroxylation. The reaction is catalysed by both the microsomal [1,2] and the mitochondrial [3] fractions of the liver. A microsomal cytochrome $P-450$ catalysing the 25-hydroxylation has been purified to apparent homogeneity from rat liver microsomal fraction [4-6]. The involvement of cytochrome $P-450$ in the mitochondrial 25-hydroxylation of vitamin $D_{3}$ was suggested by Björkhem \& Holmberg [3] from studies with intact rat liver mitochondria. More direct evidence for the participation of cytochrome $P-450$ was provided by the reconstitution experiments performed by Pedersen, Björkhem and their co-workers [7-9]. These authors have shown 25-hydroxylase activity in reconstituted systems containing partially purified cytochrome $P-450$, ferredoxin and ferredoxin reductase from rat $[7,8]$ and human [9] liver mitochondria. The 25-hydroxylase activity was, however, not higher in the reconstituted systems than in the mitochondria and the cytochrome $P-450$ fractions did not contain more than $0.2 \mathrm{nmol}$ of cytochrome $P-450 / \mathrm{mg}$ of protein. Recently we reported the isolation from rat liver mitochondria of a partially purified cytochrome $P-450$ fraction that catalysed $25-$ hydroxylation of vitamin $D_{3}$ more effectively than did intact mitochondria [10]. The cytochrome $P-450$ fraction was not pure and showed several protein bands upon gel electrophoresis. Thus it has not been possible to define the species of cytochrome $P-450$ involved in mitochondrial 25-hydroxylation of vitamin $D_{3}$.

The present paper reports the purification from rabbit liver mitochondria of an electrophoretically homogeneous cytochrome $P-450$ active in the 25 -hydroxylation of vitamin $D_{3}$. Rabbit liver mitochondria were chosen in view of the fact that it is only from this source that electrophoretically homogeneous cytochrome $P-450$ active in the 26-hydroxylation of $\mathrm{C}_{27}$ steroids has been previously isolated [11].

\section{EXPERIMENTAL}

\section{Materials}

25-Hydroxy[23,24(n)- $\left.{ }^{3} \mathrm{H}\right]$ vitamin $\quad \mathrm{D}_{3}(107 \mathrm{Ci} / \mathrm{mmol})$, $\left[4-{ }^{14} \mathrm{C}\right]$ cholesterol $(61 \mathrm{Ci} / \mathrm{mol}),\left[1-{ }^{14} \mathrm{C}\right]$ lauric acid $(26 \mathrm{Ci} /$ mol) and $\left[4-{ }^{14} \mathrm{C}\right]$ testosterone $(50 \mathrm{Ci} / \mathrm{mol})$ were obtained from The Radiochemical Centre, Amersham, Bucks., U.K. Unlabelled 25-hydroxyvitamin $\mathrm{D}_{3}$ and $1 \alpha$-hydroxyvitamin $D_{3}$ were obtained respectively from Duphar, Weesp, The Netherlands, and Lövens, Malmö, Sweden. $5 \beta-\left[7 \beta-{ }^{3} \mathrm{H}\right]$ Cholestane- $3 \alpha, 7 \alpha, 12 \alpha$-triol $(500 \mathrm{Ci} / \mathrm{mol})$ was synthesized as described previously [12]. Benzphetamine hydrochloride was generously given by Dr. B. Lindeke (Department of Pharmaceutical Organic Chemistry, Uppsala, Sweden). Vitamin $D_{3}$, deoxycorticosterone, corticosterone, sodium cholate and cofactors were obtained from Sigma Chemical Co. OctylamineSepharose 4B was prepared as described previously [13]. Fractogel TSK DEAE-650(s) was obtained from Merck, Darmstadt, Germany, Emulgen 913 from Kao-Atlas, Tokyo, Japan, and hydroxyapatite (Bio-Gel HTP) from Bio-Rad Laboratories, Richmond, CA, U.S.A. Bio-Gel HTP was mixed with an equal amount of Whatman CF-1 cellulose powder before chromatography. The remaining chemicals were of reagent grade.

\section{Enzyme purifications}

Cytochrome $P-450$, catalysing 25-hydroxylation of vitamin $D_{3}$, was purified to electrophoretic homo- 
geneity from liver mitochondria of untreated rabbits as described by Wikvall [11] with the modification that Fractogel TSK DEAE-650(s) was used instead of DE52 DEAE-cellulose.

Ferredoxin and ferredoxin reductase were prepared from bovine adrenal mitochondria as described previously [11].

Cytochrome $P-450$ was determined as described by Omura \& Sato [14] and protein as described by Lowry et al. [15], with bovine serum albumin as standard. Ferredoxin and ferredoxin reductase concentrations were determined as described by Huang \& Kimura [16] and by Chu \& Kimura [17] respectively.

Polyacrylamide-gel electrophoresis was performed with $15 \%$ polyacrylamide $(15 \%$ polyacrylamide and $0.09 \%$ bisacrylamide) slab gels $(15 \mathrm{~cm} \times 10 \mathrm{~cm} \times 0.1 \mathrm{~cm}$ and $15 \mathrm{~cm} \times 15 \mathrm{~cm} \times 0.1 \mathrm{~cm})$ containing $0.1 \%(\mathrm{w} / \mathrm{v})$ SDS in accordance with Laemmli [18]. The gels were polymerized by addition of $0.1 \%$ tetramethylenediamine and $0.1 \%$ ammonium persulphate. Electrophoresis was carried out at $170 \mathrm{~V} / \mathrm{slab}$ gel at room temperature for $2 \mathrm{~h}$. The gels were silver-stained as described by Wray et al. [19].

Two-dimensional isoelectric-focusing-SDS/polyacrylamide-gel electrophoresis was performed as described by Andersson \& Jörnvall [5].

\section{Incubation procedures}

Incubations were carried out for $1-20 \mathrm{~min}$ at $37^{\circ} \mathrm{C}$. Vitamin $\mathrm{D}_{3}, 1 \alpha$-hydroxyvitamin $\mathrm{D}_{3}, 25$-hydroxyvitamin $\mathrm{D}_{3}, 5 \beta$-cholestane-3 $\alpha, 7 \alpha, 12 \alpha$-triol, cholesterol, deoxycorticosterone, lauric acid and testosterone (62.5$250 \mathrm{nmol}$ in $25 \mu \mathrm{l}$ of acetone) were incubated with $0.05-0.1 \mathrm{nmol}$ of cytochrome $P-450,2 \mathrm{nmol}$ of ferredoxin, $0.2 \mathrm{nmol}$ of ferredoxin reductase and $1 \mu \mathrm{mol}$ of NADPH in a total volume of $1 \mathrm{ml}$ of $50 \mathrm{~mm}$-Tris/acetate buffer, $\mathrm{pH} 7.4$. Incubations with benzphetamine $(2 \mu \mathrm{mol})$ were performed with $0.1 \mathrm{nmol}$ of cytochrome P-450, $2 \mathrm{nmol}$ of ferredoxin, $0.2 \mathrm{nmol}$ of ferredoxin reductase and $2 \mu \mathrm{mol}$ of NADPH in a total volume of $2 \mathrm{ml}$ of Tris/ acetate buffer, $\mathrm{pH}$ 7.4. Incubations with vitamin $\mathrm{D}_{3}, 25$ hydroxyvitamin $D_{3}$ and $1 \alpha$-hydroxyvitamin $D_{3}$ were terminated by addition of $5 \mathrm{ml}$ of trichloroethane/ methanol $(2: 1, \mathrm{v} / \mathrm{v})$, incubations with $5 \beta$-cholestane$3 \alpha, 7 \alpha, 12 \alpha$-triol, cholesterol, lauric acid and testosterone by addition of $3 \mathrm{ml}$ of $96 \%(\mathrm{v} / \mathrm{v})$ ethanol, and incubations with deoxycorticosterone by addition of $2 \mathrm{ml}$ of dichloromethane. Incubations with intact mitochondria and vitamin $D_{3}(500 \mathrm{nmol}$ dissolved in $25 \mu \mathrm{l}$ of acetone) were performed at $37^{\circ} \mathrm{C}$ for $45 \mathrm{~min}$ with $4 \mathrm{mg}$ of mitochondrial protein and $15 \mu \mathrm{mol}$ of isocitrate in a total volume of $10 \mathrm{ml}$ of $50 \mathrm{mM}$-Tris/acetate buffer, $\mathrm{pH} 7.4$, containing $10 \mathrm{~mm}-\mathrm{MgCl}_{2}[10,20]$. Incubations with intact mitochondria and $5 \beta$-cholestane- $3 \alpha, 7 \alpha, 12 \alpha-$ triol $(250 \mathrm{nmol})$ contained $3 \mathrm{mg}$ of mitochondrial protein, $5 \mu \mathrm{mol}$ of isocitrate and $30 \mu \mathrm{mol}$ of $\mathrm{MgCl}_{2}$ in a total volume of $3 \mathrm{ml}$ of $50 \mathrm{~mm}$-Tris/acetate buffer, $\mathrm{pH} 7.4$ [11].

\section{Analysis of incubations}

Quantitative determination of 25-hydroxyvitamin $D_{3}$ was performed by h.p.l.c. with the use of an LKB 2150 h.p.l.c. pump, LKB 2151 variable-wavelength monitor, Berthold LB 503 D h.p.l.c. radioactivity monitor with a $100 \mu \mathrm{l}$ flow-through cell (solid-glass scintillator) and a LiChrosorb Si column $(150 \mathrm{~mm} \times 3 \mathrm{~mm}$ internal diam.,
$5 \mu \mathrm{m}$ particle size; Merck) for the straight-phase analysis. A Merck Hitachi 655A-11 liquid chromatograph, Merck Hitachi 655A wavelength u.v. monitor, Merck Hitachi L-5000 liquid-chromatograph controller, Merck Hitachi D-2000 Chromato-Integrator and a LiChrosorb RP-18 column $(150 \mathrm{~mm} \times 3 \mathrm{~mm}$ internal diam., $5 \mu \mathrm{m}$ particle size; Merck) were used for the reversed-phase analysis. ${ }^{3} \mathrm{H}$-labelled 25 -hydroxyvitamin $\mathrm{D}_{3}$ (10000 d.p.m.) was added to the incubations immediately after termination as internal standard to correct for recovery during the extraction and chromatographic procedures. The incubations were extracted twice with trichloroethane/methanol $(2: 1, \mathrm{v} / \mathrm{v})$. The organic phases were evaporated and the residues were transferred with trichloroethane to vials, dried down with $\mathrm{N}_{2}$, dissolved in $100 \mu \mathrm{l}$ of mobile phase and submitted to straight-phase h.p.l.c. analysis. The mobile phase was hexane/propan-2-ol $(24: 1, \mathrm{v} / \mathrm{v})$ [21] and the solvent flow was $0.7 \mathrm{ml} / \mathrm{min}$. The retention time for 25-hydroxyvitamin $D_{3}$ was about $10 \mathrm{~min}$. The fractions corresponding to authentic 25 -hydroxyvitamin $\mathrm{D}_{3}$ were collected, dried down with $\mathrm{N}_{2}$ and submitted to reversed-phase h.p.l.c. analysis. The residue was dissolved in $100 \mu \mathrm{l}$ of the mobile phase, aq. $92 \%(\mathrm{v} / \mathrm{v})$ methanol. The solvent flow was $0.5 \mathrm{ml} / \mathrm{min}$ and the retention time for 25-hydroxyvitamin $D_{3}$ was $6 \mathrm{~min}$. The amount of 25hydroxyvitamin $D_{3}$ was quantified by comparing the peak found at $265 \mathrm{~nm}$ with a standard curve obtained with different amounts of authentic 25-hydroxyvitamin $\mathrm{D}_{3}$ and corrected for recovery of the added ${ }^{3} \mathrm{H}$-labelled 25 -hydroxyvitamin $D_{3}$. Total recovery was about $65 \%$ [22].

25-Hydroxyvitamin $D_{3}$ was also quantified by isotope dilution-mass spectrometry $[4,21]$, giving essentially the same results as those obtained by h.p.l.c. The quantitative determination of $1 \alpha, 25$-dihydroxyvitamin $\mathrm{D}_{3}$ formed in incubations with 25 -hydroxyvitamin $\mathrm{D}_{3}$ and $1 \alpha$-hydroxyvitamin $D_{3}$ was performed by isotope dilution-mass spectrometry as described previously $[4,23]$.

Analyses of incubation mixtures with cholesterol and $5 \beta$-cholestane- $3 \alpha, 7 \alpha, 12 \alpha$-triol with purified cytochrome $P-450$ were performed by t.l.c. as described previously [11]. The developing solvent in the analysis of pregnenolone formation from cholesterol was cyclohexane/ethyl acetate $(3: 2, v / v)$. Analyses of incubations with $5 \beta$-cholestane- $3 \alpha, 7 \alpha, 12 \alpha$-triol were also performed by h.p.l.c. with the same instruments as described above for reversed-phase analysis. $\mathrm{N}_{2}$-dried incubation extracts were dissolved in $100 \mu \mathrm{l}$ of mobile phase. The analyses were performed with aqueous solutions and the columns were eluted isocratically. The flow rate was $0.5 \mathrm{ml} / \mathrm{min}$. The mobile phase was aq. $90 \%$ (v/v) methanol. The retention time for $5 \beta$-cholestane-3 $3,7 \alpha, 12 \alpha, 26$-tetrol was $6 \mathrm{~min}$ and that for $5 \beta$-cholestane-3 $3,7 \alpha, 12 \alpha$-triol $14 \mathrm{~min}$.

The analysis of incubation mixture with testosterone was the same as that described by Boström et al. [24]. Incubations with lauric acid were acidified and extracted once with ethyl acetate and once with diethyl ether. The organic phases were combined and washed with water until neutral and subjected to t.l.c. The developing solvent was diethyl ether/n-hexane/acetic acid (1:9:1, by vol.). The chromatoplates were analysed by radioactivity scanning. Incubations of deoxycorticosterone were extracted three times with dichloromethane and analysed by reversed-phase h.p.l.c. The analyses were performed with the same h.p.l.c. instruments as above. The mobile phase was aq. $50 \%(\mathrm{v} / \mathrm{v})$ methanol. The 
Table 1. Purification from livers of untreated rabbits of mitochondrial cytochrome $P-450$ catalysing 25 -hydroxylation of vitamin $D_{3}$

Details of the purification are given in the Experimental section. Incubations were performed at $37^{\circ} \mathrm{C}$ for $5 \mathrm{~min}$ except for incubations with intact mitochondria and cholate extract, which were carried out for $45 \mathrm{~min}$. The incubation mixtures contained $0.1 \mathrm{nmol}$ of cytochrome $P-450,2 \mathrm{nmol}$ of ferredoxin, $0.2 \mathrm{nmol}$ of ferredoxin reductase, $1 \mu$ mol of NADPH and $65 \mathrm{nmol}$ of vitamin $\mathrm{D}_{3}$ in a total volume of $1 \mathrm{ml}$ of Tris/acetate buffer, $\mathrm{pH}$ 7.4. Incubations with intact mitochondria were performed as described in the Experimental section.

\begin{tabular}{|c|c|c|c|c|c|}
\hline & \multirow[b]{2}{*}{$\begin{array}{l}\text { Protein } \\
\text { (mg) }\end{array}$} & \multicolumn{2}{|c|}{$\begin{array}{c}\text { Cytochrome } \\
P-450\end{array}$} & \multicolumn{2}{|c|}{$\begin{array}{c}\text { Vitamin } \mathrm{D}_{3} \\
\text { 25-hydroxylase } \\
\text { activity }\end{array}$} \\
\hline & & (nmol) & $\begin{array}{l}\text { (nmol } / \mathrm{mg} \\
\text { of protein) }\end{array}$ & $\begin{array}{c}\text { (pmol/min per mg } \\
\text { of protein) }\end{array}$ & $\begin{array}{l}\text { (pmol/min per nmol } \\
\text { of cytochrome } P-450 \text { ) }\end{array}$ \\
\hline Mitochondria & 17740 & N.D.* & N.D. & 0.7 & N.D. \\
\hline Cholate extract & 10996 & 2019 & 0.18 & 0.9 & 5 \\
\hline $\begin{array}{l}\text { Octylamine-Sepharose } \\
\text { and hydroxyapatite }\end{array}$ & 46.9 & 132 & 2.8 & 154 & 55 \\
\hline \multicolumn{6}{|l|}{ Fractogel TSK DEAE } \\
\hline Pool 1 & 9.9 & 12.9 & 1.3 & $<10$ & $<10$ \\
\hline Pool 2 & 0.6 & 4.2 & 8.5 & 3570 & 420 \\
\hline Pool 3 & 3.4 & 29.6 & 8.8 & $<10$ & $<10$ \\
\hline Pool 4 & 1.5 & 3.9 & 2.6 & $<10$ & $<10$ \\
\hline
\end{tabular}

* Not determined. The cytochrome $P-450$ content in intact mitochondria cannot be accurately measured because of the presence of other cytochromes and cytochrome oxidase. On the basis of the cytochrome $P-450$ content in the cholate extract, which was $0.18 \mathrm{nmol} / \mathrm{mg}$ of protein, the content in intact mitochondria can be estimated to be $0.1-0.2 \mathrm{nmol} / \mathrm{mg}$ of protein. This is essentially the same cytochrome $P-450$ content as reported for rat liver mitochondria [7].

retention time was $23 \mathrm{~min}$ for corticosterone and $49 \mathrm{~min}$ for deoxycorticosterone.

Incubations with benzphetamine were analysed for formaldehyde formation by the method of Werringloer [25].

\section{RESULTS AND DISCUSSION}

Liver mitochondrial cytochrome $P-450$ catalysing $25-$ hydroxylation of vitamin $\mathrm{D}_{3}$ was purified from untreated rabbits. The 25-hydroxylation of vitamin $\mathrm{D}_{3}$ was analysed at the different steps in the purification procedure. Table 1 summarizes the results of the purification. Chromatography of solubilized mitochondrial cytochrome $P-450$ on octylamine-Sepharose, hydroxyapatite and Fractogel TSK DEAE-650(s) resulted in four pools of cytochrome $P-450$, namely pools $1,2,3$ and 4 . Chromatography on Fractogel TSK DEAE-650(s) instead of DE-52 DEAEcellulose [11] resulted in more distinct peaks and higher resolution of mitochondrial cytochrome $P-450$. Four peaks, containing cytochrome $P-450$, were obtained in the Fractogel TSK-DEAE-650(s) chromatography, as shown in Fig. 1. The first peak was eluted with the equilibrating buffer, the second and the third in the beginning and the fourth in the middle of the $\mathrm{KCl}$ gradient. The fractions with highest cytochrome $P-450$ content from each peak were analysed by SDS/ polyacrylamide-gel electrophoresis and pooled to give pools $1,2,3$ and 4 . Cytochrome $P-450$ active in the 25hydroxylation of vitamin $D_{3}$ was present in pool 2 . The other fractions (pools 1, 3 and 4) contained cytochrome $P-450$ but showed no or only low activity towards vitamin $\mathrm{D}_{3}$. The yield of cytochrome $P-450$ in pool 2 represented about $0.2 \%$ of the cytochrome $P-450$ present in the cholate extract. The specific cytochrome $P-450$ content increased about 50 -fold, from $0.18 \mathrm{nmol} / \mathrm{mg}$ of

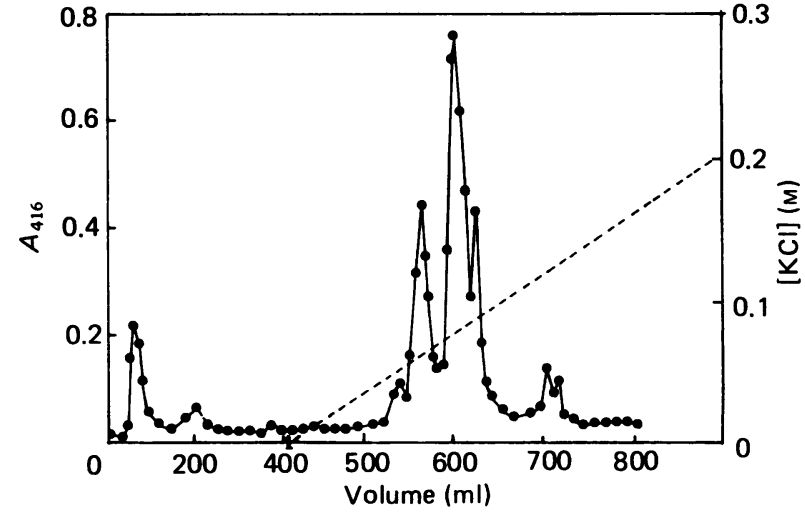

Fig. 1. Fractogel TSK DEAE-650(s) chromatography of mitochondrial cytochrome $P-450$ from livers of untreated rabbits

Cytochrome $P-450$ was solubilized, chromatographed on octylamine-Sepharose and hydroxyapatite (see the Experimental section) and applied to a Fractogel TSK DEAE650 (s) column $(1.8 \mathrm{~cm} \times 30 \mathrm{~cm})$ in $10 \mathrm{~mm}$-potassium phosphate buffer, pH 7.4, containing $20 \%$ glycerol, $0.05 \%$ Emulgen 913 and $0.1 \%$ sodium cholate. Cytochrome $P-450$ was eluted as described in the Experimental section. Fractions $(3 \mathrm{ml})$ were collected and analysed for content of cytochrome $P-450$ by measuring the absorbance at $416 \mathrm{~nm}$ (O); ----, concentration of $\mathrm{KCl}$.

protein in the cholate-solubilized extract to $8.5 \mathrm{nmol} / \mathrm{mg}$ of protein in pool 2. The 25-hydroxylase activity, expressed as $\mathrm{pmol} / \mathrm{min}$ per $\mathrm{mg}$ of protein, was about 5000 times higher in the purified cytochrome $P-450$ than in mitochondria. The yield of 25-hydroxylase activity in the isolated cytochrome $P-450$ preparation represented $17 \%$ of the activity present in mitochondria. 


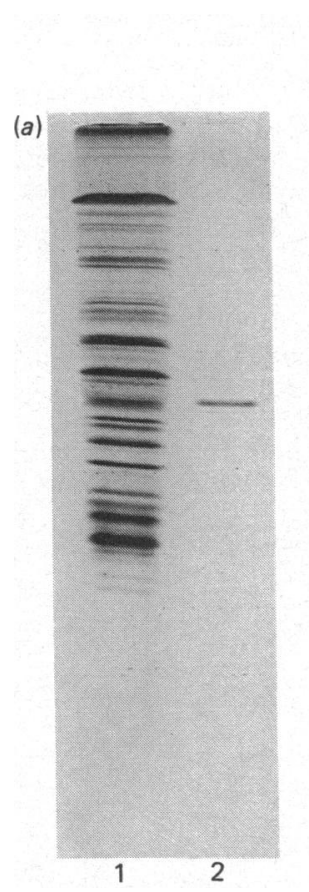

(b)

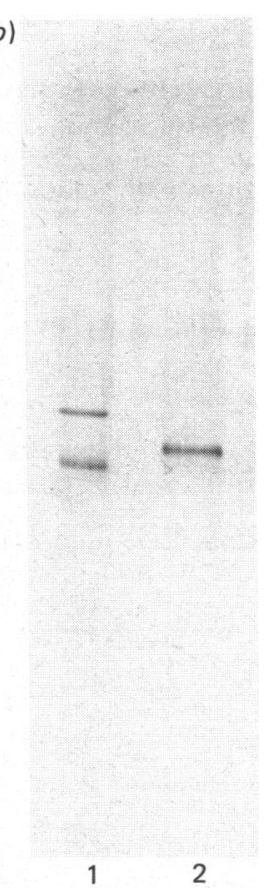

Fig. 2. Polyacrylamide-gel electrophoresis of purified mitochondrial cytochrome $\boldsymbol{P}-\mathbf{4 5 0}$ from rabbit liver

The protein samples were pretreated with SDS and 2mercaptoethanol at $100{ }^{\circ} \mathrm{C}$ for $2 \mathrm{~min}$ and submitted to polyacrylamide-gel electrophoresis in the presence of SDS. Migration was from top to bottom. (a) Gel electrophoresis in accordance with Laemmli [18] with modifications as described in the Experimental section. Stacking gels contained $3 \%(\mathrm{w} / \mathrm{v})$ acrylamide. The separating gels contained $15 \%(\mathrm{w} / \mathrm{v})$ acrylamide and $0.09 \%(\mathrm{w} / \mathrm{v})$ bisacrylamide, had a length of $10 \mathrm{~cm}$ and were $0.1 \mathrm{~cm}$ thick. Lane 1, liver mitochondria, $40 \mu \mathrm{g}$; lane 2 , mitochondrial cytochrome $P-450,0.5 \mu \mathrm{g}$. (b) The same gel system as in $(a)$ but with separating gels having a length of $15 \mathrm{~cm}$. Lane 1, mixture of cytochrome $P-450 \mathrm{LM}_{4}$ $\left(M_{\mathrm{r}} 56000\right)$ and cytochrome $P-450 \mathrm{LM}_{2}\left(M_{\mathrm{r}} 50000\right)$ from rabbit liver microsomal fraction, $0.5 \mu \mathrm{g}$ of each; lane 2 , mitochondrial cytochrome $P-450,0.5 \mu \mathrm{g}$.

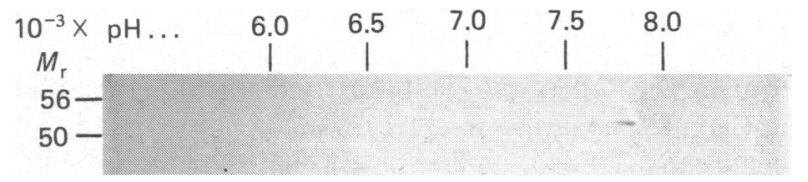

Fig. 3. Two-dimensional isoelectric-focusing-polyacrylamidegel electrophoresis of mitochondrial cytochrome $P-450$ from rabbit liver

A sample containing $2 \mu \mathrm{g}$ of mitochondrial cytochrome $P-450$ was subjected to two-dimensional isoelectricfocusing-polyacrylamide-gel electrophoresis as described in the Experimental section. Indicated are the electrophoretic migrations of proteins of known $M_{\mathrm{r}}$, namely cytochrome $P-450 \mathrm{LM}_{4}\left(M_{\mathrm{r}} 56000\right)$ and cytochrome $P-450$ $\mathrm{LM}_{2}\left(M_{\mathrm{r}}\right.$ 50000) from rabbit liver microsomal fraction. The $\mathrm{pH}$ gradient in the tube gel was determined by subjecting a parallel gel to isoelectric focusing, after which the gel was cut into consecutive $5 \mathrm{~mm}$ slices that were incubated in degassed water overnight at $4^{\circ} \mathrm{C}$ before $\mathrm{pH}$ measurement.

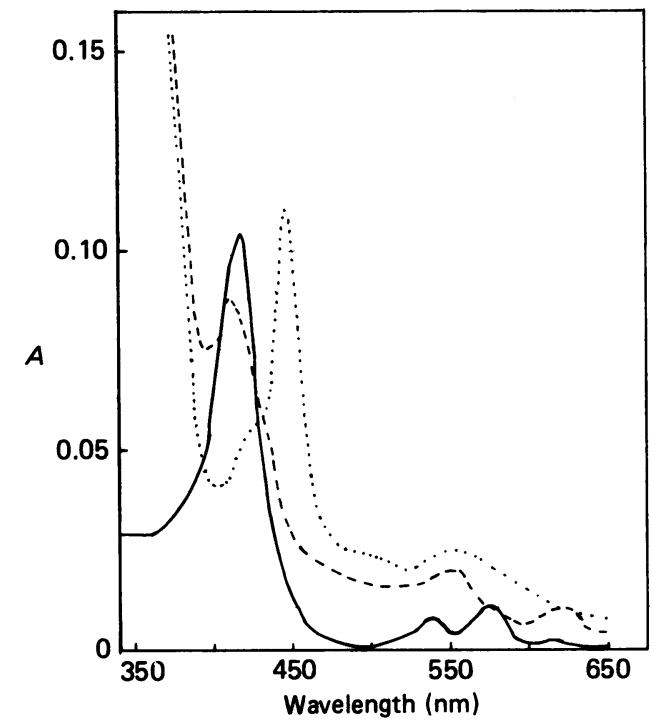

Fig. 4. Absolute spectra of purified mitochondrial cytochrome $P-450$ from livers of untreated rabbits

The concentration of the cytochrome $P-450$ was 0.56

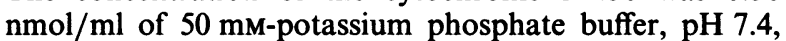
containing $20 \%$ glycerol. — $P-450 ;----$, reduced cytochrome $P-450 ; \cdots \cdots$, reduced cytochrome $P-450-\mathrm{CO}$ complex.

Fig. 2 shows the results of SDS/polyacrylamide-gel electrophoresis of the 25-hydroxylating cytochrome $P-450$. The preparation showed only one protein band, corresponding to an apparent $M_{\mathrm{r}}$ of 52000 . The $M_{\mathrm{r}}$ of the mitochondrial cytochrome $P-450$ differed from that of the microsomal cytochromes $P-450 \mathrm{LM}_{2}$ and $\mathrm{LM}_{4}$. To examine the purity of the preparation further, experiments were performed in which the cytochrome $P-450$ preparation was submitted to two-dimensional isoelectric-focusing-polyacrylamide-gel electrophoresis. A single spot with an apparent isoelectric point of 7.8 and an $M_{\mathrm{r}}$ of about 52000 was observed (Fig. 3). The spectral properties of the mitochondrial cytochrome $P-450$ are shown in Fig. 4. The fraction showed an absorbance maximum in the oxidized state at $418 \mathrm{~nm}$ and in the reduced state at $410 \mathrm{~nm}$. The absorbance maximum for the reduced CO complex was at $447 \mathrm{~nm}$. The spectral properties indicate a low-spin form of cytochrome $P-450$ [26].

The reconstitution conditions for the 25-hydroxylation of vitamin $\mathrm{D}_{3}$ were analysed in a series of experiments, and the results are summarized in Table 2 . The activity showed an absolute requirement for the cytochrome $P-450$, ferredoxin and ferredoxin reductase as well as for NADPH. Ferredoxin and ferredoxin reductase could not be replaced by microsomal NADPH-cytochrome $P-450$ reductase from rabbit liver. Fig. 5 shows that the conversion of vitamin $D_{3}$ into 25 -hydroxyvitamin $D_{3}$ was approximately linear with the amount of cytochrome $P$ 450 up to about $0.2 \mathrm{nmol}$ and with time up to $10 \mathrm{~min}$. The system was saturated with $2 \mathrm{nmol}$ of ferredoxin and $0.2 \mathrm{nmol}$ of ferredoxin reductase and with a $65 \mu \mathrm{M}$ concentration of the substrate. The apparent $K_{\mathrm{m}}$ for the 25-hydroxylation of vitamin $D_{3}$ in the reconstituted system was measured in separate experiments and was found to be $10 \mu \mathrm{M}$. This value is about the same as that 
Table 2. Reconstitution conditions for 25-hydroxylation of vitamin $D_{3}$ by the purified mitochondrial cytochrome $P-450$

Incubations were performed as described in Table 1 except for the omission of cytochrome $P-450$, NADPH, ferredoxin and/or ferredoxin reductase in some experiments. In the experiment with microsomal NADPH-cytochrome $P-450$ reductase, 1.5 units of this protein were used.

\begin{tabular}{lc} 
Components & $\begin{array}{c}\text { 25-Hydroxylation } \\
\text { (pmol/min per } \\
\text { nmol of cyto- } \\
\text { chrome } P-450)\end{array}$ \\
\hline Cytochrome $P-450$ & $<10$ \\
Ferredoxin + ferredoxin reductase & $<10$ \\
$\begin{array}{l}\text { Cytochrome } P-450+\text { ferredoxin } \\
\text { Cytochrome } P-450+\text { ferredoxin }\end{array}$ & $<10$ \\
reductase & $<10$ \\
Cytochrome $P-450+$ ferredoxin + & 340 \\
ferredoxin reductase* & $<10$ \\
Cytochrome $P-450+$ microsomal & \\
NADPH-cytochrome $P-450$ & \\
reductase & \\
$*$ Omission of NADPH from the reconstituted system \\
resulted in no detectable 25-hydroxylase activity. \\
\hline
\end{tabular}

reported in previous studies with purified cytochrome $P-450$ from liver microsomal fraction [6,27] and with partially purified cytochrome $P-450$ from liver mitochondria [8]. It might be mentioned that the concentration of vitamin $D_{3}$ in the whole liver has been estimated to be around $0.1 \mu \mathrm{M}$ [28]. No information is available concerning the concentration of vitamin $D_{3}$ in the different subcellular components of liver.

The catalytic properties of the 25-hydroxylating mitochondrial cytochrome $P-450$ are summarized in Table 3. The preparation catalysed the 25-hydroxylations of vitamin $D_{3}$ and $1 \alpha$-hydroxyvitamin $D_{3}$. In addition, it catalysed the 26-hydroxylation of $5 \beta$ cholestane- $3 \alpha, 7 \alpha, 12 \alpha$-triol. The rate of 26 -hydroxylation of this $\mathrm{C}_{27}$ steroid was 20 and 50 times higher respectively than the rate of 25 -hydroxylation of $1 \alpha$-hydroxyvitamin $\mathrm{D}_{3}$ and vitamin $\mathrm{D}_{3}$. The cytochrome $P-450$ was inactive in side-chain cleavage of cholesterol and in $11 \beta$-hydroxylation of deoxycorticosterone, reactions catalysed by cytochromes $P-450$ from adrenal mitochondria [29]. The lack of $1 \alpha$-hydroxylase activity towards 25-hydroxyvitamin $\mathrm{D}_{3}$ shows that it is catalytically distinct also from cytochrome(s) $P-450$ in kidney mitochondria [30]. The enzyme was inactive in hydroxylations of lauric acid and testosterone and in demethylation of benzphetamine, reactions that are carried out by many cytochromes $P-450$ isolated from liver microsomal fractions $[29,31-33]$.

The finding that the 25-hydroxylating cytochrome $P-450$ also catalysed an efficient 26-hydroxylation of $5 \beta$-cholestane- $3 \alpha, 7 \alpha, 12 \alpha$-triol prompted experiments in which the 26-hydroxylase activity was analysed at different steps in the purification. The ratio between the 26-hydroxylase and the 25-hydroxylase activities was about $60: 1$ in the mitochondria and remained constant throughout the purification procedure. Pool 1 from the Fractogel TSK DEAE-650(s) chromatography did not
Table 3. Hydroxylase activities in purified liver mitochondrial cytochrome $P-450$ from untreated rabbits

The incubations were performed at $37^{\circ} \mathrm{C}$ for $5 \mathrm{~min}$ with vitamin $\mathrm{D}_{3}, 3$ min with $5 \beta$-cholestane- $3 \alpha, 7 \alpha, 12 \alpha$-triol and $20 \mathrm{~min}$ with the other substrates. The reaction mixtures contained $0.05 \mathrm{nmol}$ of cytochrome $P-450$ in the incubation with $5 \beta$-cholestane- $3 \alpha, 7 \alpha, 12 \alpha$-triol and $0.1 \mathrm{nmol}$ of cytochrome $P-450$ in the incubations with the other substrates, $2 \mathrm{nmol}$ of ferredoxin, $0.2 \mathrm{nmol}$ of ferredoxin reductase and $1 \mu \mathrm{mol}$ of NADPH in a total volume of $1 \mathrm{ml}$ of $50 \mathrm{~mm}$-Tris/acetate buffer, $\mathrm{pH} \mathrm{7.4}$. The following amounts of substrates were used; vitamin $D_{3}, 65 \mathrm{nmol}$; $1 \alpha$-hydroxyvitamin $D_{3}$ and 25 -hydroxyvitamin $D_{3}$, $160 \mathrm{nmol} ; \quad 5 \beta$-cholestane- $3 \alpha, 7 \alpha, 12 \alpha$-triol, $\quad 125 \mathrm{nmol}$; cholesterol, $25 \mathrm{nmol}$; deoxycorticosterone, $30 \mathrm{nmol}$; lauric acid, $250 \mathrm{nmol}$; testosterone, $175 \mathrm{nmol}$; benzphetamine, $2 \mu \mathrm{mol}$.

\begin{tabular}{|c|c|}
\hline Reaction & $\begin{array}{c}\text { Cytochrome } P-450 \\
\text { (pmol/min per } \\
\text { nmol of } \\
\text { cytochrome } P-450)\end{array}$ \\
\hline Vitamin $\mathrm{D}_{3} 25$-hydroxylation & 395 \\
\hline $\begin{array}{l}\text { 1 } \alpha \text {-Hydroxyvitamin } \mathrm{D}_{3} \\
25 \text {-hydroxylation }\end{array}$ & 1200 \\
\hline $\begin{array}{l}\text { 25-Hydroxyvitamin } \mathrm{D}_{3} \\
1 \alpha \text {-hydroxylation }\end{array}$ & $<10$ \\
\hline $\begin{array}{l}5 \beta \text {-Cholestane- } 3 \alpha, 7 \alpha, 12 \alpha \text {-triol } \\
\text { 26-hydroxylation }\end{array}$ & 25000 \\
\hline Cholesterol side-chain cleavage & $<10$ \\
\hline $\begin{array}{l}\text { Deoxycorticosterone } \\
11 \beta \text {-hydroxylation }\end{array}$ & $<10$ \\
\hline $\begin{array}{l}\text { Lauric acid } \omega+(\omega-1)- \\
\text { hydroxylation }\end{array}$ & $<10$ \\
\hline Testosterone hydroxylations & $<10$ \\
\hline Benzphetamine demethylation & $<1000$ \\
\hline
\end{tabular}

contain any detectable 26-hydroxylase activity. Pools 3 and 4 catalysed 26-hydroxylation, but at a considerably lower rate than that catalysed by the 25 -hydroxylating cytochrome $P-450$ in pool 2 (cf. Fig. 1).

The results of the present study show that the properties of the mitochondrial cytochrome $P-450$ active in the 25-hydroxylation of vitamin $D_{3}$ are similar to those of a mitochondrial cytochrome $P-450$, active in 26-hydroxylation of $\mathrm{C}_{27}$ steroids, isolated earlier from rabbit liver mitochondria [11]. Thus the 26-hydroxylase activity, the chromatographic behaviour, the haem content and the spectral properties are essentially the same for the two cytochrome $P-450$ preparations. In a separate set of experiments (results not shown) it was found that the two preparations also show the same apparent $M_{\mathrm{r}}$ in the gel-electrophoretic system used in the present work. These findings raise the question whether the 25-hydroxylation of vitamin $\mathrm{D}_{3}$ and the 26-hydroxylation of $\mathrm{C}_{27}$ steroids are catalysed by a common cytochrome $P-450$ species in liver mitochondria.

There are several lines of evidence indicating that mitochondrial cytochrome $P-450$ plays an important role in the metabolic activation of vitamin $D_{3}$ in the liver. According to DeLuca [30] the microsomal 25-hydroxylation of vitamin $D_{3}$ is more important than the mitochondrial 25-hydroxylation in the bioactivation process under normal conditions. This contention is based on experiments mainly with male rats. However, 

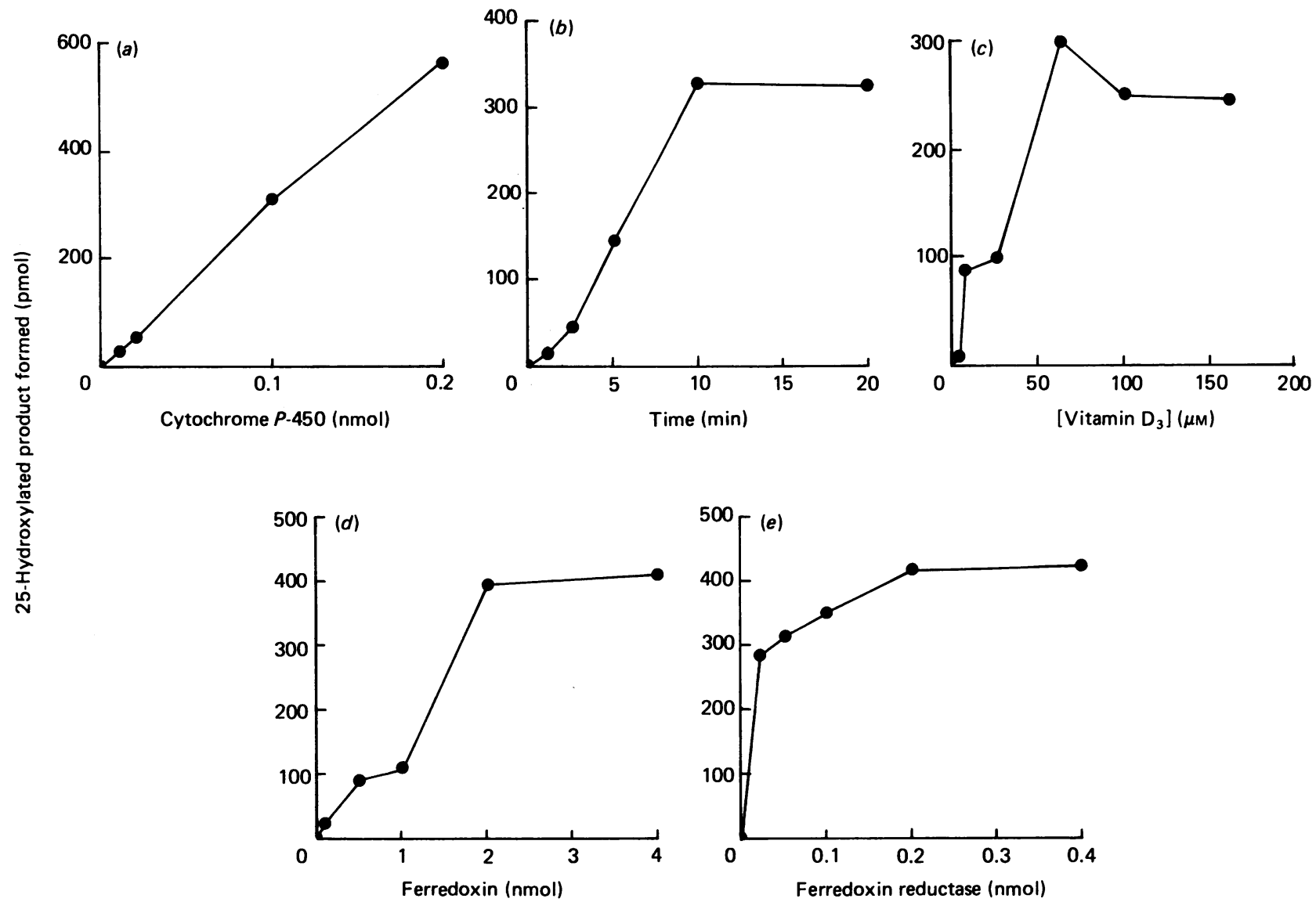

Fig. 5. Effect of cytochrome $P-450$ concentration $(a)$, time $(b)$, vitamin $D_{3}$ concentration $(c)$, ferredoxin $(d)$ and ferredoxin reductase $(e)$ concentrations on the rate of 25-hydroxylation of vitamin $D_{3}$

Incubations were performed as described in Table 1 except when the concentration of a component was varied.

the role of the microsomal fraction in 25-hydroxylation has been recently questioned. The present mitochondrial cytochrome $P-450$ from rabbit liver has a turnover for 25-hydroxylation of vitamin $D_{3}$ that is more than 100 times higher than that reported earlier for a microsomal cytochrome $P-450$ from rabbit liver [27]. Further, Pedersen and collaborators have reported that 25hydroxylation of vitamin $\mathrm{D}_{3}[22]$ as well as of $1 \alpha$ hydroxyvitamin $D_{3}$ [34] is catalysed only by the mitochondrial fraction of human liver. It might be mentioned, however, that Holmberg et al. [35] recently showed that partially purified cytochrome $P-450$ from human liver microsomal fraction was not completely devoid of 25hydroxylase activity. Andersson et al. [4] have purified to homogeneity a cytochrome $P-450$ from the liver microsomal fraction of male rats that is active in 25hydroxylation of vitamin $D_{3}$. Experiments with a monospecific monoclonal antibody showed that this microsomal 25-hydroxylating cytochrome $P-450$ was male-specific and not present in the liver microsomal fraction of female rats [5]. On the other hand, mitochondrial cytochrome $P-450$ from livers of female rats catalyses the 25 -hydroxylation of vitamin $D_{3}$ as efficiently as the same material from male rats [10]. Taken together, these results suggest that the liver mitochondrial cytochrome $P-450$ isolated in the present study plays an important role in the metabolism of vitamin $D_{3}$.
The skilful technical assistance of Mrs. Kerstin Rönnqvist is gratefully acknowledged. We are grateful to Professor Ingemar Björkhem for placing mass-spectrometric equipment at our disposal and to Dr. Inger Holmberg for valuable advice in connection with the mass-fragmentographic assay of 25hydroxyvitamin $D_{3}$ and $1 \alpha, 25$-dihydroxyvitamin $D_{3}$. This work was supported by the Swedish Medical Research Council (Project 03X-218).

\section{REFERENCES}

1. Bhattacharayya, M. H. \& DeLuca, H. F. (1974) Arch. Biochem. Biophys. 160, 58-62

2. Madhok, T. C. \& DeLuca, H. F. (1979) Biochem. J. 184, 491-499

3. Björkhem, I. \& Holmberg, I. (1978) J. Biol. Chem. 253, 842-849

4. Andersson, S., Holmberg, I. \& Wikvall, K. (1983) J. Biol. Chem. 258, 6777-6781

5. Andersson, S. \& Jörnvall, H. (1986) J. Biol. Chem. 261, 16932-16936

6. Hayashi, S., Noshiro, M. \& Okuda, K. (1986) J. Biochem. (Tokyo) 99, 1753-1763

7. Pedersen, J. I., Holmberg, I. \& Björkhem, I. (1979) FEBS Lett. 98, 394-398

8. Björkhem, I., Holmberg, I., Oftebro, H. \& Pedersen, J. I. (1980) J. Biol. Chem. 255, 5244-5249

9. Oftebro, H., Saarem, K., Björkhem, I. \& Pedersen, J. I. (1981) J. Lipid Res. 22, 1254-1264 
10. Dahlbäck, H. \& Wikvall, K. (1987) Biochem. Biophys. Res. Commun. 142, 999-1005

11. Wikvall, K. (1984) J. Biol. Chem. 259, 3800-3804

12. Cronholm, T. \& Johansson, G. (1970) Eur. J. Biochem. 16, 373-381

13. Cuatrecasas, P. (1970) J. Biol. Chem. 245, 3059-3065

14. Omura, T. \& Sato, R. (1964) J. Biol. Chem. 239, 2379-2385

15. Lowry, O. H., Rosebrough, N. J., Farr, A. L. \& Randall, R. J. (1951) J. Biol. Chem. 193, 265-275

16. Huang, J. J. \& Kimura, T. (1973) Biochemistry 12, 406-409

17. Chu, J.-W. \& Kimura, T. (1973) J. Biol. Chem. 248, 2089-2094

18. Laemmli, U. K. (1970) Nature (London) 227, 680-685

19. Wray, W., Boulikas, T., Wray, V. \& Hancock, R. (1981) Anal. Biochem. 118, 197-203

20. Björkhem, I. \& Holmberg, I. (1979) J. Biol. Chem. 254, 9518-9524

21. Holmberg, I., Kristiansen, T. \& Sturén, M. (1984) Scand. J. Clin. Lab. Invest. 44, 275-282

22. Saarem, K., Bergseth, S., Oftebro, H. \& Pedersen, J. I. (1984) J. Biol. Chem. 259, 10936-10940

23. Björkhem, I., Holmberg, I., Kristiansen, T. \& Pedersen, J. I. (1979) Clin. Chem. 25, 584-588

Received 3 August 1987/6 November 1987; accepted 21 January 1988
24. Boström, H., Hansson, R., Jönsson, K.-H. \& Wikvall, K. (1981) Eur. J. Biochem. 120, 29-32

25. Werringloer, J. (1978) Methods Enzymol. 52C, 297302

26. Haugen, D. A. \& Coon, M. J. (1976) J. Biol. Chem. 251, 7929-7939

27. Hansson, R., Holmberg, I. \& Wikvall, K. (1981) J. Biol. Chem. 256, 4345-4349

28. Holmes, R. P. \& Kummerow, F. A. (1983) J. Am. Coll. Nutr. 2, 173-199

29. Coon, M. J. \& Koop, D. R. (1983) Enzymes 3rd Ed. 16, 645-677

30. DeLuca, H. F. (1980) Harvey Lect. 75, 333-379

31. Lu, A. Y. H., Junk, K. W. \& Coon, M. J. (1969) J. Biol. Chem. 244, 3714-3721

32. Gibson, G. G., Orton, T. C. \& Tamburini, P. P. (1982) Biochem. J. 203, 161-182

33. Ryan, D. E., Thomas, P. E., Korzeniowski, D. \& Levin, W. (1979) J. Biol. Chem. 254, 1365-1374

34. Saarem, K. \& Pedersen, J. I. (1985) Biochim. Biophys. Acta 840, 117-126

35. Holmberg, I., Berlin, T., Ewerth, S. \& Björkhem, I. (1986) Scand. J. Clin. Lab. Invest. 46, 785-790 